\title{
MICROECONOMIC EFFECTS OF GROWING PUBLIC DEBT ON THE RUSSIAN ECONOMY
}

\author{
Mstislav P. Afanasiev \\ Doctor of Economics, Professor of the Department \\ of Public and Municipal Management, HSE. \\ Address: National Research University Higher School of Economics. \\ 101000, Myasnitskaya 20, Moscow. E-mail: mstafan@hse.ru
}

\section{Natalia N. Shash}

Doctor of Economics, Professor of the Department Economics and Finance, St. Petersburg Branch of the Financial University under the Government of the Russian Federation. Address: SPb Branch of the Finance Academy under the Government of the Russian Federation. Syeszhinskaya 15/17. E-mail: nat_vshu@mail.ru

\begin{abstract}
The paper represents a complex analysis of public debt as one of the major tools of microeconomic policy, through which a modern state can directly or indirectly affect the condition and development of the national economy.

The analysis results are given for modern concepts explaining how the amount of public debt affects microeconomic development. It is shown that a growing public debt may cause both a positive and a negative effect on microeconomic processes, which makes it possible to reach a conclusion about the contradictory character of debt funding the economy.

The essence and nature of the Russian Federation's public debt is revealed as an important component of the Russian economy's operating mechanism at the present time.

The RF public debt dynamics are presented and projected values of its growth are given for the years 2016-2018.

A brief description of the characteristics of RF debt policy is provided. It is noted that one of its objectives for the next few years is the need to adapt to the changing conditions in the external and domestic financial markets.

One hazard of growing public debt is identified given the structural misbalances and external economic shocks, since it may result in a bigger dependence of the national economy on external and internal borrowings, which, in turn, will provoke additional risks for the development of the Russian economy.

It is shown that in the countries with developing markets, growing public borrowings may cause negative macroeconomic consequences. It is proven that in order to enhance the stimulating effect of public debt on the macroeconomic processes the state needs to develop an efficient debt strategy, which would clearly define the economic boundaries of public debt use.
\end{abstract}

Keywords: public debt; microeconomic development; economic growth; budget policy; budget forecast; public budget; debt policy; debt strategy.

Citation: Afanasiev, M.P. \& Shash, N.N. (2016). Microeconomic Effects of Growing Public Debt on the Russian Economy. Public Administration Issues, no 5 (Special Issue, electronic edition), pp. 46-59 (in English). 


\section{Analysis of the Concepts of Public Debt Influence on Macroeconomic Development}

The issues concerning the optimal amount and structure of public debt and the consequences of its growth for the national economy have remained at the center of scientific discussions for many decades, and this therefore call for wise decisions during the development of debt policy in many countries. Moreover, the followers of various economic schools and trends often have quite contradictory views in respect of the consequences of public debt and budget deficit. For example, the classic approach implied that a growing public debt was an absolutely negative phenomenon, whereas the representatives of the historic school (like the founder of financial economics, A. Wagner) considered the deficit funding of the public budget as a fairly progressive process (Afanasyev \& Afanasyev, 2009; Wagner, 1909). This opinion was held by J.M. Keynes, since, according to him, in the periods problematic for the economy, in order to maintain the necessary level of aggregate demand, public spending must grow to fund the budget deficit and expand the amounts of public borrowings (Keynes, 1997).

Considerable results were achieved by R.J. Barro (1997); P. Diamond (1965); N.G. Mankiw, D. Romer and D. Weil (1992); F. Modigliani (1961) in the research studies concerning the development of efficient debt policy and use of government liabilities. In later periods the most interesting papers seem to have been written by W. Moore and T. Chrystol (2008); D. Sutherland and P. Hoelle (2012); J. Hanson (2007); J. Cochrane (2011); W. Gale and P. Orszag (2003). They prove that a growing public debt may have both positive and negative consequences for the national economy. At the same time, none of the above researchers give reliable conclusions in relation to the threshold values of the amount of public debt which, if exceeded, cause change of influence vector. Linear dependence between the amount of public debt and the paces of economic growth in economically developed countries is proven by $\mathrm{C}$. $\mathrm{Pa}$ tillo, H. Poirson and L. Ricci (2002), who managed to calculate the threshold values of public debt on the case of the USA. The growing interest in the identification of optimal threshold values of public debt is preconditioned by the developing debt crisis in EU countries (Misztal, 2010; Checherita \& Rother, 2010). As for the countries with forming markets, the interdependence between public debt was noted by M. Caner, T. Grennes and F. Koehler-Geib (2010); C. Reinhart and K. Rogoff (2011); Siti N., Mohd D. and Podivinsky J. (2013), and A. Schclarek (2005).

By and large, over the past few decades two approaches have formed in relation to the effect of public debt on the paces of economic growth (Kutivadze, 2012). The first one accentuates its important role in the stimulation of economic growth. In particular, it refers to the use of debt financing tools in order to maintain a stable financial system, increase public spending on human capital development and improve infrastructure. However, positive dynamics in the paces of economic growth is observed in cases where the public debt is little, whereas growth of debt liabilities is sure to affect the GDP indicators negatively (Patillo, Poirson, \& Ricci, 2004). 
The second approach draws attention to the hazards of a growing public debt, since additional cash injections in the economy provoke the growth of interest rates, strengthen inflation processes and can result in the so-called "crowding out effect" of private investments and thus contribute to the worsening of the process of capital formation and of the labor productivity growth indicators. Thus, the results of the research conducted by M. Kumar and J. Woo (2010) in relation to a group of countries (both developed and developing ones) over the period from 1970 to 2007 demonstrated that there is negative dependence between an increasing public debt and GDP growth. The obtained data, in particular, provides evidence that growth in the ratio of the amount of leverage to the GDP by 10 units results in an annual fall by 0.2 units of the real GDP level per capita. Moreover, analysis carried out by A. Schclarek on the data of 25 developed and 59 developing countries has demonstrated that in the latter there is direct negative dependence between a growing leverage and growing GDP, whereas in the developed countries no substantial interdependence has been identified between these indicators.

There is no shared vision among economic researchers about interdependence of these indicators. There is an opinion (followed by W. Easterly (2001), for example), that the feedback is there. Namely, the growth rate of public debt (and the condition of the latter) depends on the GDP growth indicators. In support of this standpoint, reference is made to a situation in the global economy in 1975, when a debt crisis, which struck countries with average income per capita in the 1980s and countries with low income in 1980-1990, was provoked by growth rates of the global economy slowing down. This position is shared by P. Krugman (2012), who believes that whenever public debt grows no bad things happen to the growth, but it is exactly when there is decline in economic growth that bad things happen to public debt.

Our analysis clearly shows that according to most of the concepts which tackle the issues of how the amount of public debt affects the growth rates of the economy, countries with forming markets (including Russia) must be very careful when increasing their public debt and strive to keep its optimal structure by choosing the most efficient tools for its financing.

Macroeconomic Development Problems of the Russian Federation in the Conditions of Structural Misbalances and External Economic Shocks

Under the new economic conditions of the past few years, low growth rates have been common for the Russian economy (in comparison to previous periods). The main reasons for this have included persistent structural misbalances and considerable drops in the prices of the major Russian export goods. Thus, an average price of Urals oil in 2015 was $\$ 51.23$, showing a substantial decline compared to 2014 , when it was $\$ 97.6(-47.5 \%)$.

After a shock at the end of 2014, which was marked by a fall in the ruble and considerable increase in consumer prices ${ }^{1}$, since the beginning of 2015 and

\footnotetext{
1 At 2015 year end, the increase of consumer prices was 11.9\% (data of the RF Ministry of Economic Development).
} 
while the situation was stabilizing in the financial sphere, the accent of the national economic policy was transferred to neutralize the consequences of external macroeconomic challenges, which negatively affected the operation results in the real sector of the Russian economy. Thus, as early as in the beginning of 2015, a set of actions was taken which included, among other things, neutralization of the effect of the sharp growth of interest rates on some sectors of the economy. However, through a budget maneuver, the RF Government managed both to stabilize the situation in the financial market and partially improve the negative effects for the real sector. According to the Ministry of Economic Development of the Russian Federation, it helped to remove the negative momentum from the correction of the internal demand and thus contributed to timely structural adaptation of the national economy to external shocks.

Nevertheless, in the first five months (from January untill May) of 2015, in comparison to the same period of 2014, the GDP decreased by $3.2 \%$. The same thing was common for other indicators: there was a fall in the sphere of investments in fixed capital (-4.8\%), industrial production (-2.3\%), and real disposable money incomes $(-3.0 \%)$. Due to the cheapening Russian national currency and industrial embargo in the first quarter of 2015, there was a considerable growth of consumer prices (on average by 16.9\%). At the same time, according to the Ministry of Economic Development of the Russian Federation, by the end of the year the growth level of consumer prices was $11.9 \%$.

In January 2016 the GDP index was $-0.1 \%$ of the previous month. Positive dynamics with seasonal correction was shown by industrial production as a whole. This was mainly due to production and distribution of electricity, gas and water. As for retail trade turnover, in the first month of 2016, the decline rate, given the seasonal correction, was $0.2 \%$, the same as in December 2015, which had been the minimal value since January 2015. The dynamics of chargeable services to the public did not change in January. The level of unemployment (excluding the seasonal factor) continued its December fall into January and was $5.6 \%$ of the economically active population.

In January, according to the estimate of the Ministry of Economic Development of the RF, the fall of the GDP in comparison to January of the previous year slowed down to $2.5 \%$ against $3.5 \%$ in December respectively. At the beginning of February, Rosstat published the first evaluation of the GDP for 2015. The nominal volume of the produced gross domestic product was $80,412.5$ billion rubles. In physical terms the GDP fell by $3.7 \%$. The specific feature of the past year was the fact that the GDP dynamics were supported by external demand, whereas all the components of internal demand showed negative trends. The fall in domestic demand (by 10.3\%) was compensated by a growth in exports (3.1\%) and a sharp decline in imports $(-25.6 \%)$, which is evidence of weak domestic demand too.

Expenses for final consumption diminished by $7.9 \%$ as a whole, including the consumer demand of households (by 10.1), and the state (by 1.8\%). Investment demand lowered by 18.3\%, including gross fixed capital formation (by 7.6\%). At the end of 2015, the following structural shifts occurred in the GDP expenses: the share of consumer and investment demand shrank by $0.6 \%$ and $0.7 \%$ cor- 
respondingly; whereas the share of net exports grew by $1.3 \%$ (goods and services exports grew by $1.1 \%$ at a time when the share of imports reduced by $0.2 \%$ ).

A negative effect on the general economic growth in 2015 was produced by a decrease in financial activity, caused by a fall in the deposit and credit activity of economic agents.

The risks for the Russian economy remain. These may be provoked by growing geopolitical tension in the world, which could cause more obstacles for Russian companies preventing their access to the global capital market and, in turn, becoming a stimulus for a fall in the value of ruble. Thus, a new rise in consumer prices and a general reduction in business activity may be provoked. Moreover, there is a hazard of a further fall in oil prices, which may speed up inflation accompanied by growing tariffs of the natural monopolies, weaken the value of the Russian currency even more, cut down on investment activity and, consequently, contribute to further capital drain.

The basic scenario for 2016-2018 implies that the regime of economic sanctions in relation to the Russian Federation will continue. Thus, in this period the subjects of the Russian economy will function under conditions of limited access to the world credit market.

\section{Vector Change in the Budget Policy of the Russian Federation in 2016-2019}

The aforementioned negative effects for the Russian economy, preconditioned by the external macroeconomic challenges and the lack of structural reforms, required correction of the budget policy. In the second half of 2015, compliance with a conservative scenario in terms of indexation of budget expenses, to a point, diminished the negative cyclic impulse. Moreover, in 2015 in order to cover the federal budget deficit and withdrawn financial means, which it had planned to use on its financing, the Russian government had to use the means of the Reserve Fund. This allowed, to some extent, a neutralizing of the negative effects provoked by a cardinal change in the external and internal macroeconomic conditions and winning additional time for adapting the level and structure of expenditure commitments to the existing budget facilities.

In order to ensure the long-term balance and sustainability of budgets, define financial capabilities for the required expenditure commitments, evaluate budget risks and take actions for their minimization, in 2015 an amendment to the Budget Code was adopted. It contains a requirement for the need to develop a long-term budget forecast.

It is supposed that this document will become a tool of a complex approach to managing budget sustainability, since it will improve the ability of the state budget to adapt to temporary macroeconomic fluctuations (medium-term budget stability, sufficiency of budget safety, expansion of the limits of budget maneuver (increased flexibility in the structure of expenses).

The contents and significance of macroeconomic and budget risks underwent quality changes in comparison to the previous budget cycle, which preconditioned the specifics of the budget policy implementation in 2016-2018. In this period, the major role of the budget is to activate the structural transformation of the Russian economy, which calls for relevant changes in budget expenses. Compliance 
with the conservative scenario in the part of formation of budget expenses will allow diminishing fluctuations in the total amount of expenses, which will help to gradually reduce the federal budget deficit.

At the same time, it is probable that in 2016-2019 the budget risks will remain high, which may result in short supply of revenues planned by the federal budget, reduction of the sources of deficit financing and the need for an increase in some areas of budget expenses.

As for the project of the federal budget for 2017 and the planned period of 2018-2019, then, in comparison to the year 2015, the revenues of the federal budget are expected to go down in 2019: from $16.9 \%$ to $15.0 \%$ of the GDP correspondingly (Table 1 ).

Table 1

Major budget indicators in 2015-2019

\begin{tabular}{|c|c|c|c|c|c|c|c|c|c|c|}
\hline \multirow{2}{*}{ indicators } & \multicolumn{2}{|c|}{$\begin{array}{l}2015 \\
\text { (fact) }\end{array}$} & \multicolumn{2}{|c|}{$\begin{array}{c}2016 \\
\text { (estimate) }\end{array}$} & \multicolumn{2}{|c|}{$\begin{array}{c}2017 \\
\text { (project) }\end{array}$} & \multicolumn{2}{|c|}{$\begin{array}{c}2018 \\
\text { (project) }\end{array}$} & \multicolumn{2}{|c|}{$\begin{array}{c}2019 \\
\text { (project) }\end{array}$} \\
\hline & $\begin{array}{c}\text { billion } \\
\text { RUR }\end{array}$ & $\begin{array}{c}\% \\
\text { of GDP }\end{array}$ & $\begin{array}{c}\text { billion } \\
\text { RUR }\end{array}$ & $\begin{array}{c}\% \\
\text { of GDP }\end{array}$ & $\begin{array}{c}\text { billion } \\
\text { RUR }\end{array}$ & $\begin{array}{c}\% \\
\text { of GDP }\end{array}$ & $\begin{array}{c}\text { billion } \\
\text { RUR }\end{array}$ & $\begin{array}{c}\% \\
\text { of GDP }\end{array}$ & $\begin{array}{l}\text { billion } \\
\text { RUR }\end{array}$ & $\begin{array}{c}\% \\
\text { of GDP }\end{array}$ \\
\hline revenues & 13659 & 16.9 & 12665 & 15.3 & 13492 & 15.5 & 13955 & 15.2 & 14823 & 15.0 \\
\hline expenses & 15620 & 19.3 & 16404 & 19.8 & 16160 & 18.6 & 15951 & 17.3 & 15962 & 16.1 \\
\hline $\begin{array}{l}\text { deficit / } \\
\text { proficit }\end{array}$ & -1961 & 2.4 & -3034 & -4.5 & -2744 & -3.0 & -1989 & -2.2 & -1139 & -1.2 \\
\hline
\end{tabular}

Source: website of the RF Ministry of Finance (www.minfin.ru)

Reduced revenues of the federal budget are caused by projected worsening dynamics of oil and gas revenues, the amounts of which will decrease from $5.8 \%$ of the GDP in 2016 down to $5.4 \%$ in 2019. As illustrated in Table 1, in the next budget cycle a gradual reduction of expenses in the federal budget is expected from 16,160 billion RUR down to 14,823 billion RUR (in nominal terms) correspondingly.

In addition, the next budget cycle will be marked by a change in the vector of the budget policy. Apart from budget consolidation, aimed at the reduction of expenditure obligations, the budget policy needs serious correction. In particular, a noticeable reduction of the "oil rent" calls for immediate change in the priorities of the budget expenses, most of which must be spent on restructuring the national economy.

Moreover, even though the budget deficit is planned to be cut from 3,034 billion RUR in 2016 to 1,139 billion RUR in 2019, there are serious doubts if these projections are feasible, since now there are no reliable grounds to expect a recovery of growth in the Russian economy in 2017-2019. In this case a fiscal gap might be expected with a further growth of budget deficit, which will result in decreasing long-term budget stability.

\section{Dynamics of Public Debt and Debt Policy of Russia}

Public debt is one of the system-forming components in the economy of any country, because its amount, structure and growth rate directly affect the devel- 
opment potential of all sectors of the national economy (Afanasyev \& Krivogov, 2007; Shash \& Afanasiev, 2014). In the conditions of potentially growing budget deficit and depleting reserves of the sovereign fund ${ }^{2}$ the tasks appear related to the need for increasing the amount of debt financing of budget expenses (including investment ones) (Shash \& Afanasiev, 2014; Tatuev, Shash, Nagoev, Lyapuntsova \& Rokotyanskaya, 2015). In the situation where the Russian economy remains in recession, constant growth of public debt is expected (Fig.).

Figure

\section{Dynamics of the RF public debt change}

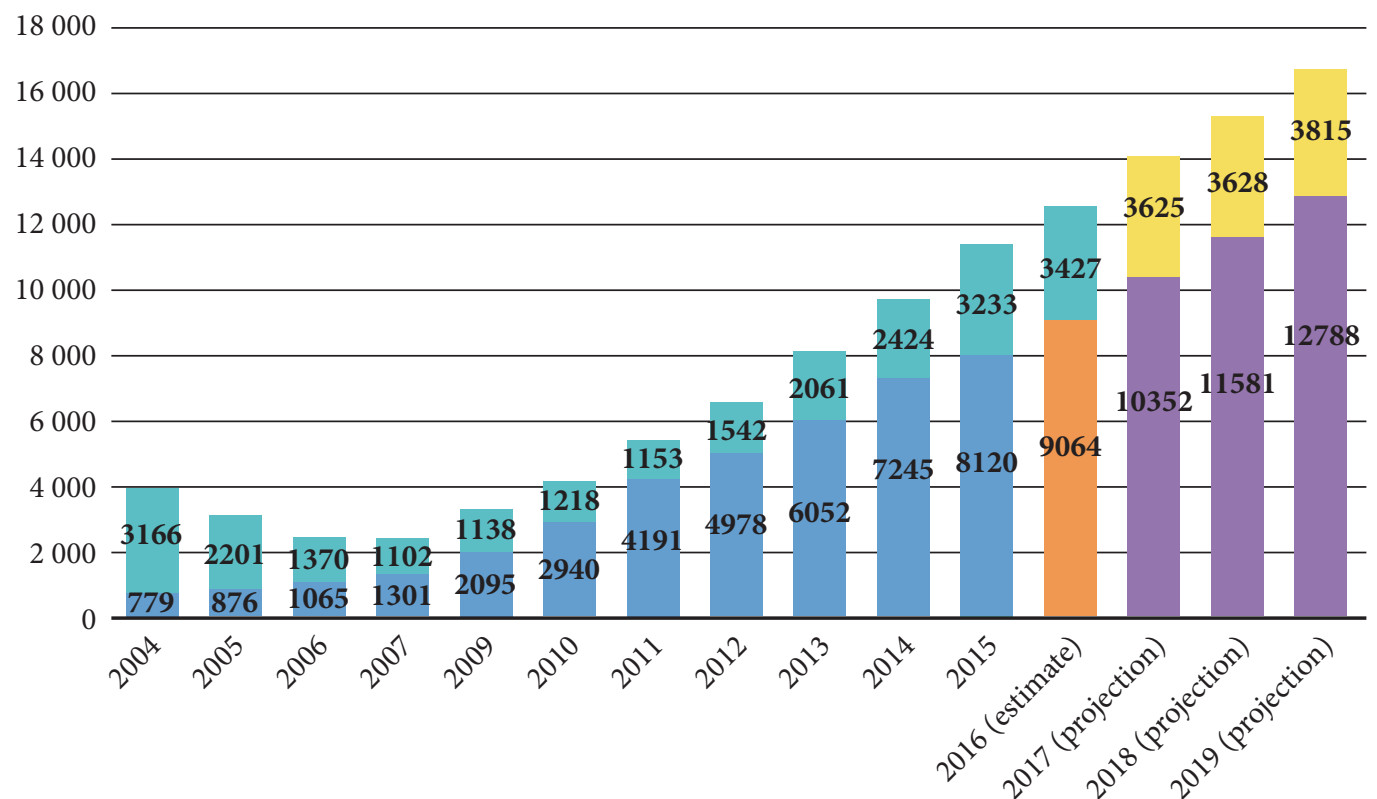

Source: website of the RF Ministry of Finance (www.minfin.ru)

As you can see, public debt is growing (and will grow) largely due to a rise of domestic debt, which will be more than 57\% in the period of 2015-2019, whereas the growth rate of external debt will stay within the limits of $11 \%$. In September 2016, an additional issue of sovereign Eurobonds was placed, with a nominal value of $\$ 1.25$ billion $^{3}$. It is obvious that the current growth of public debt securities is caused by lower revenues from traditional items of Russian exports and by the attempts to fulfill the expenditure commitments in full.

\footnotetext{
2 Sovereign Wealth Fund and Reserve Fund of the Russian Federation. The Sovereign Wealth Fund is a state investment fund, whose financial assets include stocks, bonds, property, precious metals and other financial instruments. The Reserve Fund represents part of the means of the federal budget which must be accounted and managed independently in order to perform oil and gas transfer in case oil and gas revenues are insufficient for financial provision of the above transfer.

3 The time of repayment of these debt instruments is 10 years, coupon yield is $4.7 \%$.
} 
Apart from rising public debt, there is an annual growth of expenses on its servicing, because, due to a high interest rate of the Central Bank of Russia, the costs related to public debt servicing are growing too (2011 - 2.4\%, 2016 $3.3 \%, 2019-5.3 \%)$.

Table 2

The structure and amount of Russian public debt (2015-2019), Billion rubles

\begin{tabular}{|l|c|c|c|c|c|}
\hline \multicolumn{1}{|c|}{ Indicator } & $\begin{array}{c}\mathbf{2 0 1 5} \\
\text { (fact) }\end{array}$ & $\begin{array}{c}\mathbf{2 0 1 6} \\
\text { (estimate) }\end{array}$ & $\begin{array}{c}\mathbf{2 0 1 7} \\
\text { (projection) }\end{array}$ & $\begin{array}{c}\mathbf{2 0 1 8} \\
\text { (projection) }\end{array}$ & $\begin{array}{c}\mathbf{2 0 1 9} \\
\text { (projection) }\end{array}$ \\
\hline Public debt, total & 11353 & 12490 & 13967 & 15209 & 16603 \\
\hline \%\% GDP & 15.5 & 15.1 & 16.1 & 16.5 & 16.8 \\
\hline including: public guarantees & 3170.3 & 3830.0 & 4136.0 & 4369.0 & 4612.0 \\
\hline Public domestic debt & 8119.9 & 9064.0 & 10352.0 & 11581.0 & 12788.0 \\
\hline \%\% of the total public debt & 71.5 & 72.6 & 74.1 & 76.1 & 77.0 \\
\hline including: public guarantees & 2328.8 & 2956.0 & 3146.0 & 3280.0 & 3400.0 \\
\hline Public external debt & 3233.0 & 3427.0 & 3625.0 & 3628.0 & 3815.0 \\
\hline \%\% of the total public debt & 28.5 & 27.4 & 25.9 & 23.9 & 23.0 \\
\hline including: public guarantees & 841.5 & 879.0 & 989.0 & 1089.0 & 1213.0 \\
\hline
\end{tabular}

Despite the continuous growth of public debt, the values of Russia's external debt stability coefficients remain within the threshold values (Tables 2 and 3) and it has to be considered that in the conditions of lowering reserves of the sovereign funds, in a short period the country may fully use up the available "margin of safety" in the context of the planned growth of total public debt.

Table 3

\section{Coefficients of Russia's external debt stability}

\begin{tabular}{|c|c|c|c|c|c|c|}
\hline & $\begin{array}{c}\text { "External } \\
\text { debt / } \\
\text { GDP", } \\
\%\end{array}$ & $\begin{array}{c}\text { "External } \\
\text { debt / } \\
\text { EGP } \\
\%\end{array}$ & $\begin{array}{c}\text { "Payments } \\
\text { of external } \\
\text { debt / GDP", } \\
\%\end{array}$ & $\begin{array}{c}\text { "Payments } \\
\text { of external } \\
\text { debt / EGP”, } \\
\%\end{array}$ & $\begin{array}{c}\text { "International } \\
\text { reserves / payments } \\
\text { of external debt", } \\
\%\end{array}$ & $\begin{array}{c}\text { External } \\
\text { debt per } \\
\text { capita, } \\
\text { USD }\end{array}$ \\
\hline 2004 & 36 & 105 & & & 218 & 1488 \\
\hline 2005 & 34 & 96 & 11 & 31 & 278 & 1801 \\
\hline 2006 & 32 & 94 & 11 & 33 & 279 & 2202 \\
\hline 2007 & 36 & 119 & 13 & 44 & 255 & 3267 \\
\hline 2008 & 29 & 92 & 10 & 32 & 285 & 3268 \\
\hline 2009 & 38 & 136 & 13 & 45 & 303 & 3422 \\
\hline 2010 & 32 & 111 & 10 & 36 & & 3386 \\
\hline
\end{tabular}

$4 \quad$ Annual export of goods and services. 


\begin{tabular}{|c|c|c|c|c|c|c|}
\hline & $\begin{array}{c}\text { "External } \\
\text { debt / } \\
\text { GDP", } \\
\%\end{array}$ & $\begin{array}{c}\text { "External } \\
\text { debt / } \\
\text { EGP }^{4} " \\
\%\end{array}$ & $\begin{array}{c}\text { "Payments } \\
\text { of external } \\
\text { debt / GDP", } \\
\%\end{array}$ & $\begin{array}{c}\text { "Payments } \\
\text { of external } \\
\text { debt / EGP", } \\
\%\end{array}$ & $\begin{array}{c}\text { "International } \\
\text { reserves / payments } \\
\text { of external debt", } \\
\%\end{array}$ & $\begin{array}{l}\text { External } \\
\text { debt per } \\
\text { capita, } \\
\text { USD }\end{array}$ \\
\hline 2011 & 27 & 94 & 9 & 31 & 282 & 3767 \\
\hline 2012 & 30 & 108 & 10 & 35 & 263 & 4440 \\
\hline 2013 & 33 & 123 & 11 & 40 & 217 & 5072 \\
\hline 2014 & 29 & 107 & 9 & 32 & 219 & 4100 \\
\hline 2015 & 39 & 132 & 10 & 32 & 288 & 3539 \\
\hline $\begin{array}{c}2016 \\
\text { (II quart.) }\end{array}$ & 40 & 144 & 10 & 36 & 301 & 3549 \\
\hline \multicolumn{7}{|c|}{ Threshold values of coefficients } \\
\hline IMF & $30-40-50$ & $100-150-200$ & - & $15-20-25$ & - & - \\
\hline $\begin{array}{l}\text { Audit } \\
\text { Chamber } \\
\text { of the RF }\end{array}$ & 50 & $130-220$ & - & 25 & Not less than 100 & - \\
\hline
\end{tabular}

At the same time, it should be considered that in 2015 and at the beginning of 2016 the strategy of budget deficit financing relied on the means of sovereign funds, since in this period the crediting activity was low.

Table 4

\section{Sources of federal budget deficit financing in 2017-2019, Billion rubles}

\begin{tabular}{|c|c|c|c|c|}
\hline Indicator & 2016 & 2017 & 2018 & 2019 \\
\hline Sources of deficit financing & 3035 & 2754 & 1992 & 1132 \\
\hline Use of the Reserve Fund and Sovereign Wealth Fund & 2144 & 1821 & 1143 & 130 \\
\hline Not related to the Reserve Fund and the NWF & 784 & 933 & 849 & 1002 \\
\hline Sources of domestic financing of deficit & 804 & 1136 & 1078 & 1130 \\
\hline public securities & 449 & 1050 & 1050 & 1050 \\
\hline attraction & 1151 & 1879 & 1581 & 1659 \\
\hline repayment & -702 & -829 & -531 & -609 \\
\hline privatization & $382^{*}$ & 138 & 14 & 14 \\
\hline precious metals & 0 & 4 & 2 & 0 \\
\hline receipts & 5 & 10 & 11 & 11 \\
\hline retirements & -5 & -6 & -9 & -11 \\
\hline budget loans and credits made within the country & -183 & 29 & 133 & 155 \\
\hline return & 155 & 229 & 333 & 205 \\
\hline extension & -338 & -200 & -200 & -50 \\
\hline
\end{tabular}




\begin{tabular}{|c|c|c|c|c|}
\hline Indicator & 2016 & 2017 & 2018 & 2019 \\
\hline fulfillment of guarantees & -8 & -81 & -116 & -84 \\
\hline compensation of savings & -6 & -6 & -6 & -6 \\
\hline $\begin{array}{l}\text { change in the balance of accounts of the federal } \\
\text { budget means }\end{array}$ & 270 & & & \\
\hline Sources of external financing of deficit & -20 & -203 & -229 & -127 \\
\hline borrowed sources & 82 & -32 & -75 & -29 \\
\hline attraction & 201 & 480 & 209 & 214 \\
\hline repayment & -118 & -513 & -284 & -243 \\
\hline public guarantees & -1 & -2 & -4 & -4 \\
\hline public credits & -102 & -168 & -150 & -94 \\
\hline return & 93 & 108 & 167 & 166 \\
\hline extension & -195 & -277 & -317 & -259 \\
\hline
\end{tabular}

Analysis of the major funding sources of budget deficit for the period of 2016-2019 (Table 4) has shown that in this period there will be changes in its funding ratios, because it is planned that by the end of 2016 almost $70 \%$ of the budget deficit will be compensated from sovereign funds, while by the end of the period (in 2019) almost 90\% of the deficit should be financed at the expense of government debt liabilities.

Moreover, since the third quarter of 2016 the situation in the debt markets has started to stabilize and become accompanied by lower inflation expectations and credit premiums. This is gradually causing change in the structure of deficit financing sources. Thus, the major objective of Russias debt strategy for the next budget cycle (2017-2019) is the total transfer to market financing the budget deficit.

Transfer to a qualitatively new debt strategy agrees with modern financing trends of the public budget deficit, since the use of debt financing tools has a distinct advantage. It consists of a fairly long gap between the attraction of financial resources and the repayment of debt liabilities, which gives the government greater freedom of movement.

In this respect, until the end of 2019 the Russian government plans to use debt financing tools more actively. Thus, for example, net fundraising on the domestic debt market will be 1.05 trillion RUR in 2017-2019. However, since in 2017 it will be time to repay public debt liabilities for the amount of 829 billion RUR, the net amount of borrowings will be 1.9 trillion RUR. As for the use of external borrowing tools, the main emphasis is planned to be made on supporting the liquidity of the sovereign Eurobond market. For 2017, the RF Ministry of Finance has decided to establish a limit on external borrowings equal to 7 billion USD.

According to some projections, even though the new debt strategy of Russia implies intensive growth of leverage, during its implementation in the next budget cycle the indicator of public debt will be within $20 \%$ of the GDP, which will not exceed the safe level. However, to solve the set problems, the Russian authori- 
ties need to keep the costs on public debt servicing lower than $10 \%$ and develop a number of actions for efficient adaptation of the debt policy to the dynamically changing environment in the external and, especially, in the domestic financial markets. For example, they must preclude the growth of short-term debt liabilities and their interest rates.

\section{Macroeconomic Consequences of Debt Financing for the Russian Economy}

Stability and predictability of the major macroeconomic variables is a crucial condition for ensuring favorable conditions for investments and faster economic growth. Moreover, in today's conditions, virtually every country in the world uses debt financing of the economy in order to obtain additional resources, which are necessary to start modernization processes and stimulate economic growth.

Many researchers believe that countries with their own currency have no serious financial limitations to public debt growth or capabilities for its refinancing (for example, Groneck, 2010; Krugman, 1998), because in such economies even relatively high values of public debt cannot break macroeconomic stability. However, this formula is not applicable for the countries with developing economies (including Russia). Countries with forming markets which use debt financing to mitigate external shocks can have a directly opposite effect, when a poorly controlled growth of debt liabilities can provoke new macroeconomic shocks. In this respect, attention must be paid to the risks that can be entailed by growing debt financing of the Russian economy.

One of the major hazards for Russia - a country with a large share of momentary revenues in the export structure - is in attempting to stimulate growth by making the debt larger. The result of such practice is the further pushing out of private investments and their substitution with public ones, which have proven to be rather inefficient in practice. Under the conditions of the constant debt financing of budget spending and growing debt liabilities, the state budget can end up as a tool of growth reduction, since the major problem of the continuously growing RF budget expenses is in the fact that most of them are not investments. Essentially, such actions activate the inflation spiral, which will negatively affect real personal earnings further down the road.

Furthermore, there is the probability that if the Russian authorities actively attract financial resources in the debt market, then, depending on the amounts of borrowings, interest rates will possibly go up, which will be causing further growth of expenses related to public debt servicing. Thus, for example, as early as today the interest rates for Russian debt liabilities comprise of $10-11 \%$, whereas the total amount of public debt servicing expenses can reach 3.3\% of the GDP or $4 \%$ of the expenditure budget at the end of 2016 .

Growing amounts of borrowings can reduce the trust of investors in the Russian debt instruments (in the case where the budget gaps are compensated at the expense of new loans). In the case where the debt strategy orientated on the further growth of public debt continues, Russia risks getting in a "debt trap".

Under the conditions of limited financial capabilities and slow economic recovery, the Russian government should take tough action aimed at reduction of the public budget deficit. This is related to the fact that each percentage item of budget 
deficit results in an analogous growth of the key rate of the Bank of Russia. Thus, a growing budget deficit necessitates tougher actions in monetary policy, i.e. the "price" of budget deficit is a growth of interest rates in the economy. By the end of 2016 the structural primary deficit of the consolidated budget will be around $4.0 \%$ of the GDP. The results of a simulated long-term economic growth show that the share of budget expenses in the GDP has an inverse proportion to the potential economic growth rates. An additional adverse factor is a growing share of unproductive expenses, i.e. social spending, including expenses of the pension system. A stable growth is demonstrated by defense expenses and expenses related to security and support of the public sector, which have grown by $10 \%$ (from 49 to $59 \%$ ) since 2008 .

So the problem must be solved concerning minimization of the dependence of domestic macroeconomic conditions on the dynamics of external environment conditions, and budget policy must be adapted to the low price of hydrocarbon raw materials. In order to do this, the budget policy must become more rigid in terms of lowering the level of unproductive expenses, since the structure of the currently existing Russian expenditure budget does not correspond to the conditions for achieving long-term budget sustainability and planned indicators of economic growth.

Thus, the hypothesis about a possible improvement of economic efficiency in the presence of a continuously growing public debt does not work for those countries with forming markets. It is especially true in cases where there is serious dependence of budget revenues on price misbalances in the raw material markets. In the case of Russia, an increasing amount of debt liabilities stimulates inflation processes and decreases investment activities and, thus, produces a negative effect on the level of development of the real sector of the economy (at both national and regional levels), which may be the cause of macroeconomic instability and a longterm economic recession in the country.

\section{REFERENCES}

1. Afanasyev, M.P. \& Afanasyev, Ya.M. (2009). Methodological and Theoretical Bases of the Formulation of the A. Wagner's Law. Approaches to Testing. Public Administration Issues, no 3, pp. 47-70.

2. Afanasyev M.P. \& Krivogov I.V. (2007). Finance of the Constitutional State. Public Administration Issues, no 2-3, pp. 17-36.

3. Barro, R.J. (1997). Optimal Management of Indexed and Nominal Debt. NBER WP, no 6197, pp. 1-25. 
4. Caner M., Grennes T. \& Koehler-Geib, F. (2010). Finding the tipping point - when sovereign debt turns bad. Policy research WP, no 5391, pp. 1-13.

5. Checherita, C. \& Rother, P. (2010). The Impact of High and Growing Government Debt on Economic Growth: An Empirical Investigation for the Euro Area. European Central Bank WP, no 1237, pp. 1-40.

6. Cochrane J. (2011). Understanding policy in the great recession: Some unpleasant fiscal arithmetic. European Economic Review, vol. 55, no 1, pp. 2-30.

7. Diamond, P. (1965). National debt in a neoclassical growth model. American Economic Review, no 55, pp. 1126-1150.

8. Easterly, W. (2001). Growth Implosions and Debt Explosions: Do Growth Slowdowns Cause Public Debt Crises? Contributions to Macroeconomics, vol. 1, no 1, pp. 1-24.

9. Gale, W. \& Orszag, P. (2003). The Economic Effects of Long-term Fiscal Discipline. Urban-Brookings Tax Policy Center Discussion Paper, no 8, pp. 1-30.

10. Groneck, M. (2010). A golden rule of public finance or a fixed deficit regime? Growth and welfare effects of budget rules. Economic Modeling, vol. 27, no 2, pp. 523-534.

11. Hanson, J. (2007). The Growth in Government Domestic Debt Changing Burdens and Risks. Policy Research WP Series, no 4348, pp. 1-38.

12. Keynes, J.M. (1997). The General Theory of Employment, Interest, and Money. New York: Prometheus Books.

13. Krugman, P. (1998). Financing vs. Forgiving a Dept. Overhand. Journal of Development Economics, no 29, pp. 253-268.

14. Krugman, P. (2012). Nobody understands debt. NY Times, Jan., 1. Available: http:// www.nytimes.com/2012/01/02/opinion/krugman-nobody-understands-debt.html (accused: 10 January, 2017).

15. Kumar M. \& Woo J. (2010). Public Debt and Growth. IMF WP, no 10/174, pp. 1-46.

16. Kutivadze, N. (2012). Public debt, domestic and external financing, and economic growth. Departmental WP, no 12, pp. 1-35.

17. Misztal P. (2010). Public debt and economic growth in the European Union. Journal of Applied Economic Sciences, vol. V, no 3 (13), pp. 292-302.

18. Mankiw, N.G., Romer, D. \& Weil D. (1992). A Contribution to the Empirics of Economic Growth. Quarterly Journal of Economics. The MIT Press, vol. 107, no 2, pp. 407-437.

19. Modigliani, F. (1961). Long-run implications of alternative fiscal policies and the burden of the national debt. Economic Journal, no 71, pp. 730-755.

20. Moore, W. \& Chrystol, T. (2008). A Meta-Analysis of the Relationship between Debt and Growth. Munich Personal RePEc Archive Paper, no 21 474, pp. 1-23. 
21. Patillo, C., Poirson, H. \& Ricci, L. (2002). External Debt and Growth. IMF WP, no $02 / 69$, pp. 1-45.

22. Patillo, C., Poirson, H. \& Ricci, L. (2004). What are the channels through which external debt affects growth? International Monetary Fund Working Paper, no 04/15, pp. 1-33.

23. Reinhart, C. \& Rogoff, K. (2011). From Financial Crash to Debt Crisis. American Economic Review, vol. 101, no 5, pp. 1676-1706.

24. Schclarek, A. (2005). Debt and economic growth in developing and industrial countries. Lund University Working Papers, no 34, pp. 1-39.

25. Shash, N.N. \& Afanasiev, Ya.M. (2014). The government's debt obligations in the system of financing the national debt. The science vector of the Tolyatti's State University. Series: Economics and management, no 2 (17), pp. 58-61.

26. Siti, N., Mohd, D. \& Podivinsky J. (2013). Revisiting the role of external debt in economic growth of developing countries. Journal of Business Economics and Management, no 3, pp. 968-993.

27. Sutherland, D. \& Hoelle, P. (2012). Debt and Macroeconomic Stability: An Overview of the Literature and Some Empirics. OECD Economic Department WP, no 1006, pp. 1-35.

28. Tatuev, A.A., Shash, N.N., Nagoev, A.B., Lyapuntsova, E.V. \& Rokotyanskaya, V.V. (2015). Analysis of reasons and consequences of economic differentiation of regions. International Business Management, vol. 9, no 5, pp. 928-934.

29. Wagner, A. (1909). Traité de la science des finances, vol. 1. Paris. 